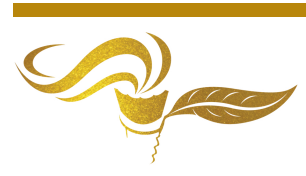

\title{
Forecasts of the Impact of the COVID-19 Pandemic on Russia's Development in 2020
}

\section{Chochiev, A. M. ${ }^{1}$ and Mokiy V. $S^{2}$}

1 Medical faculty, Kabardino-Balkarian State University, Nalchik, Russia.

${ }^{2}$ Institute of Transdisciplinary Technologies, Nalchik, Russia. Email: vmokiy@yandex.ru

* Correspondence: Email: vmokiy@yandex.ru

Received 16 November, 2020; Revised 11 January, 2021; Accepted 11 January, 2021

Available online 12 January, 2021 at www.atlas-journal.org, doi: 10.22545/2021/00148

\section{Short Letter}

The COVID-19 pandemic has exacerbated economic and social problems in Russia. According to the Russian Ministry of economic development, the largest drop in GDP in 2020 is expected in the second quarter (by $9.5 \%$ in annual terms), when the country's economy was slowed down due to quarantine. In the third and fourth quarters of 2020, GDP is projected to fall to $6.3 \%$ and $5.2 \%$, respectively. Unemployment in Russia in 2020 will be the highest since 2011 and will grow to $5.7 \%$. Real incomes of the population will decrease by $3.8 \%$ by the end of this year [3].

During the second wave of the epidemic (September-October 2020), a serious problem is arising for all regions. First of all, this is manifested in the shortage of doctors. Additional assistance - attracting medical graduates and students - is exhausting its potential. In the regions, there is a shortage of beds in hospitals and CT scanners [4].

During the pandemic, universities and other educational organizations switched to distance learning. Despite the fact that this forced measure allowed to reduce the number of infections among students and teachers, distance learning cannot fully replace face-to-face education, especially in medical faculties. As a result, students do not have a sufficient degree of mastering practical skills, which can lead to a decrease in the level of professional competencies [2].

Conclusions: Despite all measures to control the spread of viral infection, there is a steady trend towards an increase in the incidence. The population and government officials are getting rid of illusions on a global scale, understanding the long-term and, possibly, total nature of the problem. It is generally accepted that three factors play a role in the victory over a viral infection: anti-epidemiological and therapeutic measures; resources of the human immune system; mutations of the virus itself. However, in the recent history of mankind there are examples of viral pandemics (Spanish flu, Hong Kong flu, SARS, MERS), viruses that cause these diseases, suddenly appearing and suddenly losing their dangerous properties or disappearing 
altogether. This calls for rethinking the circumstances of the theory of disease caused by viruses. Simply put, it is necessary to consider them as a disease, but understand as a biological phenomenon [1].

This reassessment allows us to talk about the existence of one more, perhaps the most important factor - a natural mechanism for the formation and control of the activity of dangerous viruses in the natural environment. Probably, such a mechanism is of an electromagnetic nature. The development of a systemic transdisciplinary theoretical justification, methodological support and technological solutions based on the use of elements of this natural mechanism, is able to offer more effective ways to control the activity and spread of existing viral diseases.

\section{References}

[1] Reshetnikov, M.G. (2020). The Ministry of Economic Development has assessed the impact of the COVID-19 pandemic on the Russian economy. TASS expert. https://tass.ru/ekonomika/8535503 (accessed November 5, 2020).

[2] Report of the Agency for Political and Economic Communications (2020). The second wave of the pandemic in Russia: challenges, models of struggle, scenarios for the future. New news. https://newizv.ru/article/general/0811-2020/vtoraya-volna-pandemii-v-rossii-iv-mire-vyzovy-modeli-borby-stsenarii-buduschego (accessed November 8, 2020).

[3] Recommendations of the Russian Ministry of Education and Science on the organization of home education using distance learning technologies (2020). Ministry of Education of Russia. https://edu.gov.ru/distance (accessed November 8, 2020).

[4] Davis, P. (2018). New cancer theory. On the evolutionary history of the disease and the implications for treatment. Monthly - Essay. https://www.themonthly.com.au/issue/2018/november/1540990800/paul-davies/new-theorycancer\#mtr (accessed November 9, 2020).

Funding: This short letter received no external funding.

Conflicts of Interest: The authors declares no conflict of interest.

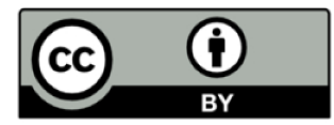

Copyright (C) 2021 by the authors. This is an open access article distributed under the Creative Commons Attribution License (https://creativecommons.org/licenses/by/4.0/), which permits unrestricted use, distribution, and reproduction in any medium, provided the original work is properly cited.

\section{About the Authors}

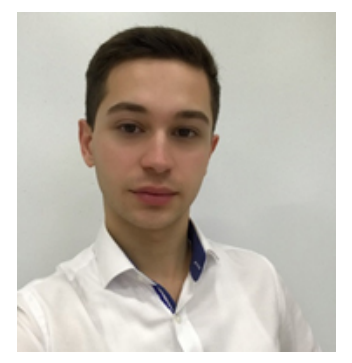

Azamat Chochaev is a 5th year student at the Faculty of Medicine, Kabardino-Balkarian State University, Russia. Member of the Academy of Excellence in the Scientific Educational Medical Cluster "North Caucasian", Russia. A participant and winner of numerous interregional and international conferences. Volunteer of the Multicenter observational study of Epidemiology of Cardiovascular Diseases in the regions of the Russian Federation. Third survey ("ESSE-RF3"). 


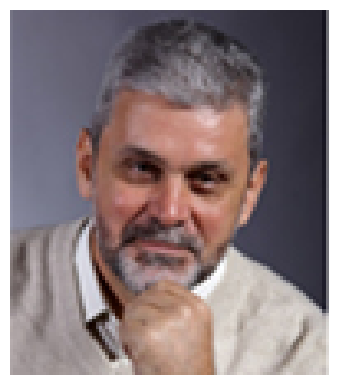

Dr. Vladimir Mokiy is the Head of the Russian School of Transdisciplinarity (http://td-science.ru); Head of the Scientific Research Laboratory of Transdisciplinary Planning and Forecasting in Kabardino-Balkarsky State University, Russia (from 1996 to 2003); Director of Institute of Transdisciplinary Technologies, Russia (from 2007 to present); Member of the Russian Philosophical Society (from 2015 to present); Member of the Society of Architects of Russia (from 2013 to present); Member of the International Academy of Organizational Sciences, Russia (from 2016 to present); and Member of the Research Group Systems Science and Philosophy of the Bertalanffy Center for the Study of Systems Science (BCSSS), Austria (from 2017 to present). complete bibliography of Dr. Vladimir Mokiy can be found by following this link: http://td-science.ru/index.php/kabinet-direktora/26-eng/473-curricu-lum-vitae. 